\title{
Agenciamentos da benzedura: o sistema de cura no Quilombo da Casca/RS1.
}

\author{
Cauê Fraga Machado \\ Doutorando do PPGAS/MN/UFRJ
}

Resumo: A partir da etnografia realizada no Quilombo da Casca, Mostardas/RS, descrevo o "sistema de cura casqueiro", que tem na benzedura seu ponto de articulação. Ancorado em relatos etnográficos de benzedeiras e de pacientes, procuro discutir com dois conceitos caros à antropologia da saúde: 0 de "itinerários terapêuticos" e o de "intermedicalidade". Ambos aparecem como noções apriorísticas para descrição, de modo que proponho que o acontecimento da benzedura seja descrito pelos "agenciamentos" que opera, sendo tal conceito melhor para exposição detalhada do sistema de cura local, que será tratado como "rizomático", capturando, conectando e descartando tratamentos, baseado na criatividade das benzedeiras, de um lado, e dos próprios pacientes, de outro.

Palavras-Chave: quilombos, saúde, benzedura, agenciamentos.

\footnotetext{
${ }^{1}$ Gostaria de agradecer a José Carlos dos Anjos pela orientação da monografia que deu origem ao artigo, bem como a Fundação Cultural Palmares pelo prêmio no Concurso Nacional de Pesquisa sobre Cultura Afro-Brasileira, Comunidades Tradicionais e Cultura Afro-Latina, edição 2010. Além deles, os comentários em diferentes momentos de Sergio Baptista, Ceres Victora, Claudia Fonseca, Luiz Fernando Dias Duarte, Otávio Bonet, Fátima Tavares e Ana Popp. Pela leitura cuidadosa da versão final agradeço a Evandro Bonfim. Por último, mas não menos importante, a todos os casqueiros que abriram suas vidas e suas casas para mim.
} 


\title{
Blessing (benzedura) as assemblage: the healing system of Quilombo da Casca / RS
}

\begin{abstract}
Based on the ethnography carried out in Quilombo da Casca, Mostardas / RS, I describe the "casqueiro healing system" assuming blessing as its pivotal joint. Grounded in ethnographic accounts of blessers (benzedeiras) and patients, I put into discussion two major concepts regarding health anthropology: that of "therapeutic itineraries" and that of "intermedicality." Both take for granted many aspect of description, so I propose to understand blessing as an act of assemblage. Such agency based concept is more suitable to detailing local healing systems, which will be treated as "rhizomatic", capturing, connecting and discarding treatments based on the creativity of the healers on the one hand and the patients themselves on the other.
\end{abstract}

Key words: quilombos, health, benzedura, assemblages.

\section{Bendicimiento como ensamblaje: el sistema de curación en Quilombo da Casca / RS}

Resúmen: A partir de la etnografía em el Quilombos da Casca, Mostardas/RS, se ofrecerá la descripcíon del "sistema de curación Casqueiro" que tiene en el bendicimiento su punto clave. Anclado en los relatos etnográficos de curanderos y pacientes, se pondrá em revisión dos conceptos caros a la antropología de la salud: los "itinerarios terapéuticos" y la "intermedicalidade". Ambos se muestran nociones a priori, por lo que propongo tomar el bendicimiento como movilizando "ensamblajes" que actuan para lograr la sanacíon. El concepto brinda una exposición más detallada del sistema de curación locales, los cuales serán tratados como "rizoma", capturando, la conectando y descartando los tratamientos, basada en la creatividad de benzedores, por un lado, y los pacientes en el otro.

Palabras clave: quilombos, la salud, benzedura, ensamblajes. 


\section{Introdução}

Neste artigo discuto uma prática/técnica que vem assegurando a saúde das pessoas e das terras no Quilombo da Casca/RS desde "o tempo que a memória alcança": a benzedura. E, em conjunto com essa, os acontecimentos envolvendo a busca pela cura de enfermidades e infortúnios. Com base nos dados do trabalho de campo que realizei nessa comunidade, descrevo histórias de benzedeiras que falam sobre diferentes tratamentos. $\mathrm{O}$ aprendizado da benzedura aparece como herança via parentesco, aliada à vontade individual de aprender fórmulas e por em prática o dom. Entre as fórmulas e o dom há um continuum de possibilidades, improvisos, adivinhações que são acionadas na escolha do tratamento. Os "pacientes", por seu turno, combinam de modo criativo a benzedura com outras práticas terapêuticas na busca da cura.

A natureza eminentemente etnográfica do texto visa descrever os acontecimentos em que diferentes tratamentos, benzedeiras e pacientes entram em agenciamentos. Não pretendo realizar um debate mais aprofundado com a vasta bibliografia sobre benzedura, me detendo na ideia de agenciamentos, que segundo Deleuze (2004)2, é "[...] uma multiplicidade que comporta muitos termos heterogêneos e que estabelece ligações, relações entre eles, através das idades, sexos, reinos - de naturezas diferentes. Assim, a única unidade do agenciamento é o co-funcionamento: é a simbiose, uma 'simpatia"' (: 84). Aqui se encontra o primeiro distanciamento dos estudos de "itinerários terapêuticos", focados nas práticas de "auto-atenção" e, por isso, voltando o olhar para os "enfermos" (ou para "carreira", segundo Menéndez, 2003). Buscarei demonstrar a importância de dar atenção para todos e tudo que os agenciamentos unem e dividem, sem definir a priori quem pode ou não falar melhor sobre as práticas ligadas ao cuidado com a saúde. Especialistas, leigos e coisas3 serão - no sentido sugerido aqui - interlocutores. Os eventos onde a busca pela cura acontecem é que serão descritos, não priorizando histórias de vida ou "carreiras", mas o corte espaço-temporal, os acontecimentos. Aqui o primeiro afastamento da ideia de "intermedicalidade", pois "medicina tradicional", "medicina alternativa", "biomedicina", "religião", "auto-atenção", "auto-medicação", "benzedura" não serão tomados como a priores que se relacionam hierarquicamente ou não; excluído uns, conectando outros; criando "zonas de contato". Mais uma vez, serão os agenciamentos que serão descritos, os cortes e divisões classificatórias serão a posteriores extraídos a partir de falas nativas.

Para dar conta de tal intento divido o artigo em três partes: na primeira apresento dados sobre a morfologia social e sobre o território e paisagem de Casca; na segunda apresento dados sobre benzedeiras do local; na terceira descrevo diferentes tratamentos que incluem o engajamento ativo dos pacientes na destruição dos infortúnios, além da tentativa de controlar as forças da inveja e do olho grande sobre os animais. É importante, ainda, mencionar o lugar central da terra ou território para essa cosmologia. Na conclusão buscarei

2 Como poderemos notar, ao longo do texto, junto com a formulação de Guattari e Rolnik (1996) a noção de agenciamento é capaz de expandir o entendimento etnográfico e não o contrário, enclausurar o fluxo da etnografia em algum conceito.

3 Coisa, segundo Ingold (2002) traz consigo a ideia de vida, diferente do objeto que seria estático. 
contrapor, a partir da síntese dos acontecimentos descritos, o que chamarei de "sistema casqueiro de cura" - rizomático4 - às noções consagradas às terapêuticas ditas tradicionais de "itinerários terapêuticos" e de "intermedicalidade".

\section{A Comunidade de Casca.}

A Comunidade5 Quilombola de Casca, ou apenas Casca, como boa parte dos moradores a chamam, situa-se a aproximadamente 150 quilômetros do município de Porto Alegre (Capital do Rio Grande do Sul), tendo seu principal acesso nas proximidades do quilômetro 135 da RS-T101. Pertence ao município de Mostardas. Referências importantes são o mar (Oceano Atlântico) e a Lagoa dos Patos, entre os quais, em uma faixa de terra plana, com horizonte infindável ao observador, situam-se as chácaras dos moradores.

Ainda que o território reivindicado pelos casqueiros6 junto ao Governo Federal compreenda a totalidade de 2. 490, 4663 hectares7, o grupo de parentela que lá vive divide a terra em pequenas chácaras. Além disso, sobrepõe-se a essa divisão a divisão por descendência, ou familial, na qual as referidas chácaras estão organizadas, geralmente, por proximidade entre os descendentes desta ou daquela família. É comum ouvir como referência ao local de residência comentários do tipo: "a Sarai mora lá pros lados da falecida Glória”. Glória, mãe de Sarai. Seus descendentes têm suas casas e chácaras reunidas como se formassem uma única grande chácara. E assim com os outros grupos de parentesco. A gente desse ou daquele morador, vivo ou morto8.

Afora isso, a ajuda mútua e uma relação de parentesco bastante elástica permitem dizer que as divisões da terra são sobrepostas por múltiplos pertencimentos até chegarmos na configuração total do território que é reivindicado, como uma real unidade. Que, no entanto, pode ser a qualquer momento dividida e reorganizada; sempre dependendo de quem narra os eventos e aponta localidades. É assim que surge uma divisão bastante mencionada: a Casca de cima e a Casca de baixo, como se fossem duas comunidades. A Casca de cima compreende a parte do território que fica entre a

4 O uso de Rizoma aqui tem a ver com uma ideia de sistema aberto como é possível observar ao longo da obra de Deleuze e Guattari. Os autores atentam , também, para ideia de que assim como estruturas sempre comportam rizomas, o rizoma ele mesmo não poderia ser puro, portanto níveis de estrutura sempre passam por ele. "Contra os sistemas centrados (e mesmo policentrados), de comunicação hierárquica e ligações preestabelecidas, o rizoma é um sistema acentrado não hierárquico e não significante, sem general, sem memória organizadora ou autômato central, unicamente definido por uma circulação de estados. Um rizoma não começa nem conclui, ele se encontra sempre no meio, entre as coisas, inter-ser, intermezzo. A árvore impõe o verbo 'ser', mas o rizoma tem como tecido a conjunção 'e... e... e...”" (Deleuze \& Guattari, 1995: 33-37). O que bem traduz o sistema de cura casqueiro, como veremos.

5 Leite (2002) justifica o uso de tal termo da seguinte forma: "O uso da palavra 'comunidade' constitui parte do vocabulário já existente na localidade [...] faz parte não só do discurso dos moradores e herdeiros de Casca como também dos agentes pastorais, funcionários da administração municipal, políticos e fazendeiros locais - sugerindo, portanto, tratar-se de uma expressão largamente utilizada, em diversos contextos e com múltiplos significados. Embora considerando a importância assumida pelo conceito de comunidade na própria construção da Antropologia (Stocking, 1983) interessa aqui manter sua referência, tal como é usada pelos moradores, para identificar e descrever Casca em relação aos outros contextos locais, situados a partir das fazendas, bairros periféricos e balneários. A 'comunidade', neste caso, alude a um tipo específico de unidade ou todo, embora nunca fechado ou isolado, e pode ser substituída ou equivaler à localidade, laços entre eles, à parentela mais ampla, ao conjunto de experiências e à história comum. Neste sentido é que os parentes de fora também são incluídos como “da comunidade”" (:74, nota 4).

${ }^{6}$ Maneira como usualmente os moradores chamam a si mesmos, aqueles da Casca: casqueiros.

7 A exceção da praia (território de importância magico-social) o Quilombo da Casca teve suas terras tituladas. A parcela de terra que teve sua escritura definitiva entregue à associação de Moradores compreende a parte habitada e pequenas lavouras dos moradores. A situação fundiária modificou-se bastante desde a última vez que estive lá, os relatos que tenho giram principalmente em torno do problema do arrendamento das terras, agora proibido. Sobre os não avanços nas titulações e na política de terras para quilombos ver Anjos (2011).

8 Para um relato pormenorizado e análise mais abrangente e completa sobre o território da Casca, suas divisões, pertencimentos, medidas, localização, cf. Leite (2002). 
RS-T101 e o mar; a de baixo situa-se entre a Lagoa dos Patos e a RS-T1019. Relacionados a cada uma "das Cascas" grupos de parentesco distintos, mas que se relacionam por novos casamentos, apadrinhamentos, amizade. Contudo, um aparente incômodo se expressa nas palavras daquele que fala sobre as pessoas da Casca do lado oposto (em referência ao lado da Casca em que vive).

\section{Benzedeiras.}

Nesta parte, descrevo alguns processos de cura, seja de pessoas, de animais ou da lavoura, a partir do ponto de vista das benzedeiras. Para curar, um agenciamento com a sobrenatureza e a natureza, ou seja, o estabelecimento de relações sociais com e uma relação social com plantas, ervas, pretos e pretas velhas, exus e pomba giras e orixás se fazem necessárias. O que estabelece como fundamental para o processo de cura uma socialidade alargada que vai do humano ao não-humano sem constrangimento algum, colocando em cheque a epistemologia biomédica - o que tratarei na conclusão. Quem tem o "dom" de curar opera por meio de uma epistemologia não-disjuntiva, na qual biológico, social e cosmológico não estão separados. Aliás, são conceitos que não se aplicam aqui.

Os principais infortúnios encontrados na Casca são os ligados à terra (a boa terra para plantar, aquela onde tudo nasce e cresce), à doença nos animais, à fofoca, ao "olho grande", ao "quebranto", além do sapinho nas crianças e dos machucados como cortes, feridas, cobreiro e até mesmo ossos quebrados. Rezas, ervas que atuam por infusão, sucção, afumentação, diálogo com divindades, e o poder que as mães têm sobre o corpo de seus filhos constituem um sistema de cura específico e local. Nele as benzedeiras ocupam lugar de destaque.

De acordo com Oliveira (2000) as benzedeiras, assim como os xamãs, transitam entre mundos e fazem os "clientes" compreenderem a vida. É por isso que uma compreensão da cosmológica local se faz necessária para uma aproximação com os significados elaborados em relação ao que é curar. A morte de uma ovelha, na complexa cosmologia local, é antes fruto do "olho grande" de determinado vizinho do que consequência de alguma doença/peste ou da genética/biológica animal. Portanto, não é apenas um problema veterinário, mas, além disso, e mais do que isso é um problema cosmológico ligado ao bem viver; à cosmologia local podemos aproximar a teoria Zande da causalidade, tal como apresentada por Evans-Pritchard (2005), nela, bem como na casqueira, nada acontece ao acaso, sempre haverá um agente causador. Se a biomedicina pode servir a tal sistema é pela capacidade que esse tem de conectar-se a outros sistemas de cura. As consultas com a Dra. Pauleti (médica da família na época) na Associação de Moradores, a ida a hospitais e o uso de remédios farmacêuticos em nada são contraditórios com o sistema de cura.

Dizem lá, por exemplo, que os médicos nem sempre sabem o que fazem, receitam remédios errados, não conversam com os pacientes, não se relacionam. Desse modo, não podem muitas vezes entrar em agenciamento com o sistema de cura local, seus atendimentos nem sempre possuem a eficácia curativa buscada. O contrário também é verdadeiro: existem ótimos médicos e esses são procurados e indicados pelos moradores no famoso boca-a-boca. Pelo que me contam, em Mostardas, não tem nenhum médico bom, o melhor é o Dr. 
Nilson, que é veterinário. Consultas médicas boas só no Hospital de Clínicas ou no Hospital de Pronto Socorro, ambos em Porto Alegre.

Observando um dia de atendimento pela doutora na Associação de Moradores, pode-se ver pacientes saindo e indo diretamente à casa de Dona Rosa, uma benzedeira. Isso acontece sem que nenhum dos sistemas contradiga o outro - penso que grande parte dos médicos não considera eficaz o tratamento via benzedura, mas não tenho como generalizar, nem mesmo tive contato mais aprofundado com a Dra. Pauleti a fim de conhecer melhor suas opiniões sobre tal assunto - eles podem e, muitas vezes, precisam se conectar. Aí que a ideia de agenciamentos e das conexões que compõem, que fazem bons encontros com o corpo e com a pessoa se aproxima das práticas locais.

O sistema de cura é um só, a partir do qual se busca noutros sistemas aquilo que possa produzir bons encontros, ser incorporado simbioticamente ainda que nem sempre a relação seja harmônica. A multiplicidade do real assim exige: o que está em jogo é curar-se de algum infortúnio, operar relações que englobem a totalidade da pessoa, daí os usos da biomedicina. Passo agora às estórias das benzedeiras.

Sarai é filha de sangue (ou de barriga, como se diz na Casca) da "falecida" Dona Glória. Essa sim foi grande benzedeira e fez história das suas curas. Tive a oportunidade de ouvir de vários moradores os feitos de tal senhora. Dizem que salvou muitas vidas, que as crianças eram a sua "especialidade". Curou muitas. Fez até festa de Cosme e Damião na Casca. Era excelente parteira. Dona Glória também era de religião1o, de Nação (culto aos orixás). Pela parte de religião, Sarai, é filha de Mãe Jussara, a quem se refere simplesmente como mãe. De acordo com Sarai, meu trabalho só poderia ficar completo seu eu conhecesse Mãe Jussara, ela é quem sabe tudo da religião. Por parte das duas mães (de barriga e de santo), tem mediunidade e poder de curar. Às vezes não precisa nem de ervas, nem de comunicação com as divindades, basta um pensamento forte.

Certa vez, na granja em que trabalha como cozinheira, as coisas não andavam bem, era seca, era bicho na plantação, era "tudo de ruim". Sarai fechou os olhos e começou a pensar, pensar em afastar todo o mal da lavoura de arroz, pois dali provinha seu sustento, o de seus amigos e parentes, além de gostar muito do dono da granja. Conta, ainda, que a maior tristeza é ver uma lavoura toda queimada, toda estragada. No outro dia, após passar a noite pensando, a lavoura começou a vingar.

Desde pequena, sempre teve mediunidade, mas nunca gostou de ideia de benzer, muito menos a de entrar para a religião, mas sempre lhe diziam que tinha de entrar. Foi somente no episódio no qual sua filha teve uma doença demandada11 (que será explicado adiante), que ela acreditou e entrou na religião. Hoje é seu maior prazer, uma alegria só, sempre se lembrará de sua filha se levantando no hospital. Diz que quer abrir uma casa de religião na Casca, mas ainda não trouxe suas "coisas de religião" (objetos sagrados do batuque/nação) de Porto Alegre, só as de Umbanda; em sua casa na Casca tem um pequeno altar.

\footnotetext{
${ }^{10}$ Ser de religião ou Nação são maneiras de se dizer pertencente ao batuque, religião de matriz africana de culto aos orixás, diferente da umbanda que cultua caboclos e pretos velhos.

11 Importante notar que na cosmologia casqueira, assim como em muitas africanas e ameríndias, causas naturais para situações como doença e morte são quase inexistentes. Ademais, assim como entre os Azande, a ideia é que não existe nada sem causa, portanto ao buscar explicações para doenças estamos diante de teorias complexas de causalidade.
} 
Conta que todos na Casca sabem do seu dom, por isso é muito procurada. Alem de benzer, faz feitiços também. Sua filha, Josi, conta que devido ao preconceito elas são segregadas de muitos eventos na Casca, por isso usam suas guias sempre escondidas na alça do sutiã. Diz que muita gente que já encomendou feitiço da sua mãe e conseguiu o que queria as exclui da convivência.

Para cobreiro, Sarai, benze com três ramos verdes, água e faca parar cortar tal infortúnio. Aprendeu observando sua mãe de sangue. Para o quebrante e para o sapinho ela ensina as mães que a procuram como benzer, diz para elas passarem a língua com movimentos em cruz sobre a testa da criança e recitar:

\author{
"Eu te pari \\ Eu te Criarei \\ Quebrante e \\ Inveja e \\ Mal olhado \\ Que te botarem \\ Eu te tirarei”
}

Além disso, possui um preto velho, que dizem ser muito bom. Ela não o conhece, mas quem por ele foi atendido sabe de sua eficácia curativa. Além disso, joga cartas, por parte do "povo" cigano, e fez um axé de Orunmilá12, para a vidência.

Outra benzedeira, Dona Alzira, senhora já de idade avançada, também possui fama de boa benzedeira. Quando perguntava a alguém sobre quem eu deveria procurar para saber sobre benzedura para lagarta da lavoura, sempre respondiam: "vai na velha Alzira". Dona Alzira aprendeu com sua avó, Dona Maria, a benzer sapinho e cortes, até mesmo ossos quebrados. Diz que suas filhas possuem o dom, mas ainda não precisaram, por isso não benzem. Mas um dia elas serão benzedeiras, é de família, o dom aparecerá quando precisarem dele, porque aquilo que é de ensinar ela já ensinou.

Com um retalho de pano, agulha e linha ela costura os infortúnios do paciente, ele recita e ela vai costurando:

\title{
“Carne quebrada \\ Nervo rendido \\ Osso ofendido"
}

A relação (agenciamento) metonímica entre tecido, agulha, linha, reza, paciente e seu dom, é estabelecida no ato de rezar e costurar. Após o ritual, Dona Alzira, guarda o retalho em uma gaveta. Pode usar o mesmo retalho para benzer outros. O pedaço de pano ali fica, sendo usado, e as enfermidades do paciente sanam, só depois tal retalho pode ser jogado fora.

Com sua tia Alice aprendeu tudo sobre chás. Dor de barriga, dor nas costas. Para tudo existe uma planta. Sobre a benzedura para lagarta de lavoura, Dona Alzira, diz que usava um livrinho de rezas, que já perdeu. Ia a três cantos da lavoura e orava, deixava o quarto canto aberto para que a lagarta fosse embora. Assim dizimava as pestes. Atualmente, não benze mais lavoura nenhuma. Dona Alzira, atenta para a não cobrança da benzedura, cobrar acaba com o dom. Caso seja da vontade do paciente/ cliente, ele poderá dar um presente depois.

12 Orixá ligado à adivinhação, por isso ligado aos jogos (carta, búzios, sementes de cola) e ao Ifá, oráculo que deve sempre ser consultado para se tomar qualquer atitude em religiões afro-americanas na religião. Em certas religiões, Orunmilá e Ifá se confundem. Além disso, existe Oxalá de Orumilaia, também ligado à adivinhação, ao jogo e a visão. 
Já Seu Quincas benzia perna quebrada e tudo que era tipo de machucado também. Agora com sua fé em Jesus Cristo através de uma denominação evangélica, largou a benzedura. Aqui, como pode-se notar a seguir, o agenciamento entre benzedura e o cristianismo pentecostal reorganiza, melhor, re-equaciona rizomáticamente os saberes do sistema de cura. A benzedura articula, mas seus agenciamentos são heterogêneos.

Conta que tinha muita fofoca, as explicações para as doenças eram sempre porque alguém tinha demandado algo, daí a pessoa para se vingar se benzia e demandava algo de volta. Com a lavoura a mesma coisa: o canto que ficava aberto era utilizado para mandar a lagarta em direção à lavoura de alguém que não se gostasse (dado suplementar àquele de Dona Alzira). O agenciamento com o cristianismo pentecostal permite, também, falar das práticas consideradas maléficas dentro da benzedura. Hoje utiliza somente os chás e os óleos: o de capivara e o de jacaré. De acordo com Seu Quincas, são esses os dois melhores remédios. Tais óleos curam tudo, da gripe até a maior fraqueza que se possa ter; para o homem do campo a fraqueza é uma das piores doenças, "o cara não consegue fazer nada" (Seu Quincas).

Atualmente, está muito difícil conseguir esses óleos porque o IBAMA proíbe a caça. O uso do óleo de capivara em conjunto com o paracetamol é um santo remédio, tira o resfriado na mesma hora. Além disso, Seu Quincas conhece um incontável número de ervas que podem ser utilizadas na forma de chás para curar diversas enfermidades. Conta que certa vez andava muito fraco, não conseguia mais trabalhar, uma dor nas costas muito forte, pensava que ia morrer. Foi então que orou, pediu a Deus para que o ajudasse. No dia seguinte acordou com um "espírito" de colher chá, andou por todo pátio pegou uma imensa quantidade de ervas e preparou com água, ferveu, referveu, deixou esfriar e tomou com fé. E não é que se curou?

Seu Quincas aprendeu a fazer partos também, fez o de sua filha mais nova, inclusive. Conta que antigamente a mulher não deitava, como fazem hoje nos hospitais, só subia na cama bem na hora em que o bebê ia nascer. Ficava de cócoras na guarda da cama e se segurava em uma corda amarrada no teto, para não cair, daí o parteiro/a ajudava a empurrar o neném para fora, depois cortava o cordão umbilical e limpava a criança. Fazia parte do trabalho das parteiras, alimentar a mãe e ajudar na casa, pois nem a mãe nem a criança podiam fazer esforço algum. Trabalhar, entrar em contato com a luz, sair da cama, nem pensar!

Seguindo os agenciamentos, passamos a afirmações do tipo: "o olho grande ou a inveja é o pior feitiço que existe". Muitas vezes a pessoa nem sabe que o tem e mesmo assim, por meio de tal magia, é capaz de fazer outros adoecerem e até mesmo lhes matar. $\mathrm{O}$ olho grande faz mal para humanos e para não-humanos13, crianças, adultos, lavouras, plantas e animais que seguidamente adoecem por causa dele.

Dona Carmen conta que benze contra esse mal utilizando brasa. Pega um copo com água e uma tesoura para pegar as brasas no fogão à lenha, e, além disso, as folhas de arruda. São sempre três ou sete. Depende do número de pessoas que se desconfia que colocaram olho grande. Se for três, são três brasas, três folhas de arruda. Se for sete, a mesma coisa. É a própria pessoa que

13 Ainda que grande debate em torno dos "grandes divisores" na antropologia ocorra, ao menos, desde Latour (1996), o sentido aqui é aquele mais próximo dos nativos, em que é possível distinguir um do outro completamente, sem que isso signifique que os males e as bendições não digam respeito as duas classes de entes. 
desconfia quem deve apanhar a brasa. A cada brasa colocada no copo d'água se diz um nome, se afundar é porque aquela pessoa colocou olho grande. Aqui novamente a teoria nativa da causalidade, além dela um sistema oracular próprio às técnicas de benzer. Daí durante a noite se deixa as folhas de arruda e a tesoura em cruz em cima do copo, no outro dia se joga a água na frente de casa, ou em água corrente. Assim se corta o olho grande por um bom tempo. Importante mencionar que para além de um sistema oracular, a benzedeira está e é a única apta a ter uma real visão do que acontece com seus pacientes, sejam humanos ou não, a visão se difere da adivinhação, é como nos ensinamentos de Dom Juan a Castañeda, quando enxergar não é o mesmo que ver. No caso da benzedura não se pode aprender a ver, deve-se nascer com esse dom. Ademais, somente vendo ou adivinhando o agente causador se pode extirpar o mal.

Boa conhecedora de plantas que é, Dona Carmen, comenta sobre o poder curativo do horo. Essa planta é poderosa, funciona como chá, cura até diabetes e colesterol. Serve para banhos religiosos (Dona Carmen é de religião, Umbanda e Nação - ambas religiões de matriz africana) também. Além disso, ele age por sucção, o horo chupa doenças do corpo. Quando seu Minem (esposo de Dona Carmen) foi queimado por um bicho cabeludo, Dona Carmen colocou uma folha de horo em cima da queimadura, a folha ficou preta e a queimadura diminuiu, assim foi fazendo, até que a última folha do horo tirou toda a queimadura.

Uma das benzedeiras mais famosas na Casca na época em que estive em campo era Dona Rosa. Sua fama se espalhou rapidamente. A maior parte das pessoas, quando eu perguntava sobre quem benzia, respondia: "vai na Velha Rosa". Mesmo outras benzedeiras como Sarai, Dona Alzira e Dona Carmen a indicavam. Mesmo os evangélicos falam muito bem de Dona Rosa. Dizem que já é de família de bons benzedores, seu pai, o Falecido Gaspar, e sua avó, a Falecida Alice, foram os melhores de toda a Casca. Agora Dona Rosa, de volta a Casca, vem cumprir seu destino. Benzer, ajudar, curar.

Nascida na Casca, mas criada em Porto Alegre, Dona Rosa conta que desde os seis anos de idade tem o dom de benzer. Encontrou um senhor na rua, viu que ele estava abatido e perguntou o que ele tinha, tal homem contou que viera da Bahia e estava desenganado. Disse ao senhor que o curaria, pediu a Deus que o ajudasse, deu-lhe um banho de ervas e passou um bife de carne de gado em sua cintura. Dias mais tarde o mesmo homem, "explodindo" de felicidade, a encontrou, contou-lhe que estava curado e lhe presenteou com uma estátua de Pai José de Angola, Preto Velho que ela carrega consigo desde aquela idade. Aqui um agenciamento de tipo diferente daquele que Seu Quincas entre sistema de cura casqueiro e pentecostalismo, a religião de matriz africana se equaciona como soma, como potencializador das técnicas de benzer já existentes no território do Quilombo.

Conta que morava na cidade com sua mãe, e que essa não gostava da mediunidade da pequena Rosa, não aceitava tal dom. Quando alguém que não gostava visitava sua casa, corria para trás da porta e soprava, assoviava até a pessoa ir embora. Sua mãe ficava "louca", batia nela. Conta que apanhou muito para não exercer sua mediunidade, mas não adiantou, ela precisava cumprir seu destino.

Aos dez anos de idade, recebeu pela primeira vez Pai José de Angola, mas só ficou sabendo quatro anos mais tarde. Numa praia onde só havia pescadores ela entrou no mar, mergulhou e quando saiu já não era mais ela. Saiu com voz bem grossa, de velho. Os pescadores queriam "pegar” ela, porém um deles, o 
mais velho, disse: "ela não tá sozinha!" Os outros riram, não acreditaram. O pescador mais velho repetia, falava para ouvirem a voz dela (dele). Foi então que o Preto Velho chegou no pescador e falou: "tu tem uma filha que não anda. Tem que carregar ela pra tudo”. Ele negou. O Preto Velho afirmou. Os outros pescadores acusaram, contando que sim, ele tinha uma filha doente.

O Preto Velho perguntou quanto o pescador lhe daria se curasse sua filha, ele respondeu que não tinha nada, era um humilde pescador. Pai José de Angola ordenou que trouxesse a guria. Levou a menina até a beira do mar, deitou ela no chão, passou a mão em suas pernas e em seu rosto, nos braços. Esticou toda ela. Depois disse com sua voz de velho: "agora levanta!" A menina, quase caindo, conseguiu levantar e caminhou. Depois disso o Preto Velho foi para uma pedra, sentou e dali já era a pequena Rosa novamente. Não sabia o que tinha acontecido. Depois disso o pescador não podia vê-la que se atirava a seus pés para agradecer. Só que ela não sabia de nada. Somente quatro anos mais tarde lhe contaram o história.

Dona Rosa benze com folha verde, com água, com faca e com tesoura. Depois de benzer planta na terra a doença, essa não volta mais; ou então despacha em água corrente. Quando quem benze é o Pai José de Angola, Dona Rosa conta que sente sua mão engrossar ficar igual a mão de um homem velho, depois não lembra mais de nada. Assim como Sarai sobre seu Preto Velho, sabe que ele é bom pelo o que os outros lhe contam. Da mesma forma que Dona Alzira, diz que não pode cobrar pela benzedura, nem mesmo aceitar agradecimento. $O$ paciente não pode agradecer nem pagar. Isso pode acarretar na extinção da mediunidade. Caso alguém agradeça, ela não pode aceitar, tampouco tocar em dinheiro que lhe seja ofertado por benzer. No entanto, os presentes são bem-vindos, esses depois de um tempo fecham o ciclo da cura. Completa comentando que após o pôr-do-sol e ao meio-dia não se deve benzer. São as horas inteiras.

Dona Rosa tem muito orgulho de sua religião, diz que é a coisa mais linda que existe, é tudo para ela, afinal foi seu Preto Velho quem a salvou. Afirma ser a sua religião a verdadeira religião africana, diz que a Umbanda vem se desvirtuando, os instrumentos estão errados. Tambor é só na Nação, no batuque. Isso acontece porque não se aprende como antigamente. Aprendia-se religião na cozinha. Ela tinha que preparar pratos para sua mãe e para seu pai de santo. Saber fazer bem todas as comidas e saber todos os nomes em Iorubá. Tinha que conhecer cada planta, era preciso ficar uma semana só olhando as folhas, tinha que saber de que orixá era e para que servia, o que ela curava.

Dona Rosa, conta que na Casca ela se curou de todas suas dores. O local é o ideal para a religião, a natureza é ótima. A única coisa que falta é o cruzeiro para o Bará. O mundo físico de Casca é ideal para a comunicação com o Orun (terra dos orixás). De forma semelhante ao descrito por Anjos (2004) ao falar do Quilombo de São Miguel e da religião de matriz africana, onde um encontro sagrado entre territórios ocorre, no qual o terreiro de Mãe Toti reencontra "as condições mais propícias que são aquelas em que o território-mato é adjacente ao território-sagrado da casa de religião" (:103).

\section{Agenciamentos.}

Conforme bem definido e resumido por Félix Guattari e Sueli Rolnik, o agenciamento é "noção mais ampla do que as de estrutura, sistema, forma, etc. 
um agenciamento comporta componentes heterogêneos, tanto de ordem biológica, social, maquínica, gnosiológica, imaginária” (1996: 317). É nesse sentido que a leitura da benzedura será realizada aqui; a partir de uma aproximação com o sistema (menor que os agenciamentos que é capaz de realizar) de cura local, é possível, também, reinterpretar as causas dos infortúnios, como vimos acima, por meio de suas "multi-causalidades" (Oliveira, 2004). Levar a sério o que as benzedeiras locais contam sobre os processos de cura nos leva a saltar de uma explicação biomédica, de causalidades lineares, para uma explicação cosmológica, na qual incontáveis episódios estão envolvidos na doença (ver Oliveira, 2004). O sistema de cura local será, como já anunciado, lido através dos agenciamentos que mobiliza. A cura é um sistema de relações que precisam se acomodar, se reorganizar, para que a vida prossiga da melhor forma. Passo agora a descrição de tratamentos, ressaltando a importância e o papel ativo e criativo dos pacientes, que são, portanto, "agentespacientes".

Numa das manhãs em que estava na casa de Seu Toninho e de Dona Nana, fui convidado por seu filho e por sua nora (José Henrique e Solange, respectivamente) para ir a uma farmácia na Solidão14, com a finalidade de levar Luís Henrique, filho dos dois, para consultar com o Dr. Nilson. Nessa farmácia, ouvindo dos pais o que se passava com a criança, a atendente chama o doutor. Tal doutor vem da casa dos fundos, cumprimenta o casal e o guri, pede ao último que sente e abra a boca, pede aos pais que comentem o que está acontecendo com a criança. Dá uma olhada na garganta (já que segundo os pais o problema é "o" gripe), toca em seu pescoço - tudo ao mesmo tempo em que ouve o relato dos pais. Ao final, receita um antibiótico, um xarope para a tosse, um remédio para o congestionamento nasal e um calmante à base de maracujá para que Luís durma bem. Na volta, fico sabendo que o "Dr. Nilson" na verdade é um veterinário, e que antigamente possuía um consultório no qual prestava atendimento a pessoas e fazia internações, também. No entanto, por motivo de denúncia, fora cassado. Ao perguntar sobre o atendimento no posto de saúde da localidade, fico sabendo que nem sempre há médico e que, além disso, o doutor já é conhecido, já cuida de toda família há muito tempo. É o Dr. Nilson quem salva o pessoal na hora do aperto, quando não sabem o que fazer é para lá que eles vão. "Não é que ele sabe das coisas?”, comentam.

Nesse caso, de modo claro, podemos observar a importância do relato feito pelos pais e das ações/movimentos realizados pelo menino, para que junto com o veterinário um diagnóstico certeiro se realize. O que não difere muito do tipo de relação estabelecida entre médicos e pacientes da Casca. Contudo, gostaria de ressaltar e enfatizar que mesmo no tipo de relação que opera por diagnóstico o paciente também será agente. Todavia, interessa nesse caso a relação que não se baseia no diagnóstico (Nathan, 2004) entre aquele que cura, aquele que é curado, outras pessoas e objetos envolvidos. Um tipo de agenciamento que implica em atividade criativa tanto para o que cura, quanto para aquele que busca a cura. O que, como estamos vendo, no sistema de cura casqueiro, cuja predominância dos curadores é composta pelas benzedeiras, fará um deslocamento tal como aquele que o adivinho faz em relação ao psicanalista, segundo Tobie Nathan: o interesse pela doença se desloca do "visível para o invisível, do individual para o coletivo e do fatal para o recuperável" (Nathan, 2004: 21).

${ }_{14}$ Localidade do município de Mostardas/RS. 
Voltando aos casos a partir da questão do diagnóstico. No primeiro Seu Quincas discute com Tita, sua sobrinha, não um diagnóstico, mas tratamentos e suas implicações no ouvido de Seu Ozório, todos casqueiros. Era uma tarde ensolarada do verão do ano de 2007, passara algumas horas do almoço e a família de Seu Quincas voltava do culto na igreja Tabernáculo da Fé15. Chegaram da igreja Seu Quincas, Dona Geni, Ozeas, Jizar, Tita, além de dois pastores, para tomar o café da tarde. Parecia ser costume que ao término do culto os praticantes da religião fossem a casa de Seu Quincas tomar café, falar sobre a igreja, além, é claro, de colocar o "papo" em dia. Falar sobre os vizinhos (quase todos parentes), sobre o gado, sobre a lavoura, sobre os mais diversos assuntos que envolvem o trabalho no campo.

$\mathrm{Na}$ cozinha, perto do fogão à lenha, sentados em cadeiras dispostas em um grande círculo à volta da mesa, tomamos chimarrão - prática comum na casa. Nesse dia um assunto reteve a minha quase total atenção: Seu Ozório (sogro de Tita) estava doente, com dor de ouvido. Tita foi quem comentou o história.

Ela pergunta a Seu Quincas se estava certo colocar álcool no ouvido para curar a dor, já que dentro do ouvido habita um bicho que produz a cera. $\mathrm{O}$ perigo, de acordo com Seu Quincas, é embebedar o tal bicho. Por isso, não é a melhor alternativa. Um remédio que é muito bom é o "leite da teta de uma mulher grávida”, essa sim é a melhor alternativa para curar esse tipo de dor. Lembra que se usa o álcool (com arnica16, de preferência) para as dores no corpo, passar tal substância numa perna que dói embebeda a dor, que assim acaba. O álcool embebeda a dor - que vai se extinguindo com o uso continuado desse remédio - e também o bicho da cera do ouvido. Deixar o bicho da cera do ouvido bêbado não é saudável.

No segundo caso, vemos a importância da forma diferenciada de percepção e visão do mundo para tratar doenças ligadas às demandas. Sarai conta como entrou para a religião de matriz africana (o batuque gaúcho), narrando o episódio em que fora demandado a sua filha um encosto. Diz que não queria entrar de modo algum para a religião, mas quando Josi, sua filha, tinha nove meses entrou em coma sem explicação alguma, a doença de sua filha a chamou.. Sarai levou a menina a tudo quanto foi hospital e nada de resolver o problema. Dona Glória, mãe de Sarai, mandou levar a neta a um terreiro. Sarai não quis. Sua mãe lhe disse: "se levar a criança ao hospital ela vai morrer, isso é demanda”.

Devido ao desespero de ver que nenhum médico fazia sua filha melhorar, aceitou o conselho de sua mãe. Foi até o terreiro; o pai-de-santo disse que a menina tinha um encosto. Conta que estava tudo "pronto" no terreiro, entrou com a criança e dali em diante não viu mais nada. Então o pai-de-santo disse: "agora a criança vai dormir o sono dela e depois acordar, após isso pode até levar no hospital se quiser”.

Depois do sono, Sarai, descrente, levou a menina para o hospital; lá foi encaminhada para a UTI (Unidade de Tratamento Intensivo). Certa hora, enquanto uma criança morria na UTI, todo mundo correndo para tentar fazer algo, ela vê sua filha de nove meses sentada na cama, tirando o soro do braço. Desde então tem "compromisso" com a religião.

\footnotetext{
15 A igrejinha fica no pátio de Seu Quincas, lá acontecem encontros semanais entre os moradores que são os chamados fiéis, isso sempre aos sábados. Um sábado por mês contarem com a presença do Pastor vindo da Tabernáculo da Fé do município de Tramandaí.

16 Planta medicinal, geralmente usada em combinação com álcool para "afumentação". Serve para aliviar dores, para picadas de insetos, etc. Há quem diga que arnica é boa para quase tudo.
} 
No terceiro caso, podemos observar a importância da percepção e da extensão do mal do corpo humano para o corpo de animais de sua propriedade. O que acontece também para objetos, casas, lavouras e outras pessoas. Dona Carmen, também de religião afro, teve de voltar a benzer recentemente porque o olho grande estava muito forte na Casca. Além de cumprir os rituais ligados à Nação (batuque gaúcho) e à Umbanda no final de ano, para proteger sua casa, teve que descobrir quem estava colocando "olho" em suas ovelhas.

No final de 2008, suas ovelhas começaram a adoecer, algumas chegaram mesmo a morrer. Seu esposo, Seu Minem, vacinou, deu remédio e tudo. Não adiantou. É claro, na concepção casqueira, para olho grande não existe remédio, só benzedura. Segundo Dona Carmen o olho grande é o pior feitiço que existe, ele é capaz de matar. A pessoa pode ter o olho grande e nem saber. Por isso benzeu suas ovelhas, usando brasa, arruda, tesoura e um copo d'água. Não deu outra, ao pensar no primeiro vizinho que desconfiara ter olho em suas ovelhas, a brasa afundou na água, confirmando a desconfiança e cortando o mal olhado. Aqui a adivinhação no sentido clássico, haja vista o sistema oracular da benzedura local. As ovelhas doentes ficaram boas e nenhuma a mais adoeceu.

No quarto e último caso, podemos verificar a importância da ação dos atingidos na busca da segurança da vida e da saúde. Nesse caso, o feitiço contra Dona Rosa recai sobre seus netos, que precisam junto com a mãe, Neli, filha da benzedeira, decidir entrar ou não para religião para que fiquem mais fortes e protegidos contra ações desse tipo. Os netos Drika e William estiveram diante da morte quando quase morreram afogados na praia da Solidão (Mostardas/RS) no verão de 2012. Em Porto Alegre, tiveram de passar longo período de recuperação no Hospital Nossa Senhora da Conceição. De acordo com a mãe deles, o que acontecera foi culpa de "uma velha" lá da Casca, que "anda fazendo feitiço" para a avó das crianças. Odacir, pai de santo próximo dos envolvidos, confirmou no jogo. Assim, além dos cuidados médicos, uma série de feitiços, além de presentes para Iemanjá - que devolveu as crianças -, foram realizados.

Willian nunca quis saber de religião. Já Drika sempre gostou de participar dos batuques, fazer novos axós (roupas de religião) e “dançar na roda”. É claro aos olhos dos sábios da religião que se trata de uma futura grande mãe de santo. Dizem que todo mundo tem santo, e que a proximidade excessiva com ele é perigosa, pois uma boa distância deve ser mantida com o orixá (ver Rabelo \& Brito, 2011: 192-4). Por isso, sempre cuidaram de Drika para que a Iansã dela soubesse que ainda era cedo para pedir para comer na cabeça de sua filha17. Os acontecimentos na praia resultaram em uma mudança drástica nesse cuidado, quando não era mais apropriado manter distância, mas sim aproximar os orixás. Assim, Willian e Drika fizeram um aribibó (ritual envolvendo sacrifício de aves para o orixá de cabeça), e Tomas, o irmão mais novo, um banho de Ebis (caramujos de Oxalá).

\section{Conclusão}

José Maurício Arruti (2008) chamou atenção, ao falar sobre saúde quilombola, para a necessidade de políticas e teorias que deem conta do reconhecimento das especificidades desses grupos, em suas "formas de

${ }_{17}$ Aqui trata-se do cuidado dispensado às crianças para que não necessitem passar pelos rituais iniciáticos muito cedo. Dar de comer na cabeça a um santo pode se referir tanto ao borido (obrigação de aves), quanto ao apronte (obrigação envolvendo assentamento do orixá e sacrifício de seu correspondente animal de quatro pés/patas). 
organização social e cultural”. Contudo, o mesmo autor, aponta para necessidade do estudo da "intermedicalidade" - o que aparentemente ultrapassaria e cruzaria a dicotomia entre medicina indígena e biomedicina (ver Follér, 2004) - e do "campo prático dos agentes terapêuticos", como agenda para os estudiosos dos quilombos. Para o autor o estudo desses "dois campos" somados ao estudo da "auto-atenção" promoveria um alargamento do conhecimento antropológico sobre esses grupos, assim como uma melhoria nas políticas de promoção da saúde específicas. Gostaria terminar esse texto em primeiro lugar com a ideia de que os dados etnográficos apontam para a não existência do que vem sendo chamado de "intermedicalidade18" no Quilombo da Casca. Como podemos ver o sistema de saúde pode ser melhor compreendido através da noção de agenciamentos, o que não exclui a biomedicina, mas "a convida para arena" apenas quando benzedeiras e agentes-pacientes pensam pertinente. Outrossim, o que Fóller (2004) também chamou de "zona de contato" entre os Shipibo-Conibo e os médicos não se realiza no caso aqui exposto de modo "intermedical", havendo troca e acumulo de saberes. Remédios alopáticos assumem outros significados ao serem utilizados em conjunto com ervas e tratamentos de benzedeiras, ao passo que o tratamento da benzedeira não é receitado pela medicina que opera via diagnóstico e receitas; mas ocorre através do que? De outras modalidades perceptivas relacionadas ao bem estar corporal, vegetal, animal e territorial e certa concepção de causalidade, da adivinhação oracular, envolvendo religião de matriz africana e também, no caso do Sr. Quincas, cristianismo pentecostal.

Outro ponto a discordar nos estudos das chamadas "medicinas tradicionais" é o conceito de "itinerários terapêuticos". Como vimos ao longo do texto não se trata de procurar diferentes "opções" e "combinações", mas de agenciamentos singulares e específicos, que apesar de algumas fórmulas e do dom das benzedeiras, depende da criatividade compartilhada entre aquele que cura e o doente, ao menos.

Assim, as relações entre o corpo e o território apontam pra uma ontologia não-disjuntiva onde a pessoa e a terra onde se vive e se encontram as ervas sagradas estão imbricadas. Além disso, os parentes, a religião, objetos, folhas, rezas, água, animais, etc. fazem parte do encadeamento de coisas que se relacionam de modo a estender as partes do corpo e a noção de pessoa para fora da noção biológica de corpo - que, de acordo com Camargo Jr. (2005), suporia um "imaginário científico" correspondente à racionalidade da mecânica clássica - um isolamento de componentes (peças, partes do corpo para a reintegração da totalidade a posteriori).

Em suma, busquei demonstrar relações de continuidade e complementaridade entre corpo-pessoa-território-cosmos a partir de agenciamentos específicos que, especialmente, nas técnicas de benzer permitiem às benzedeiras da Casca/RS transitar entre mundos, viajando sem constrangimentos numa epistemologia não-disjuntiva, que conecta o necessário para realizar a cura, fugindo assim, da ideia de medicina convencional $\mathrm{X}$ medicina tradicional. Com base nos dados etnográficos propus que as noções de itinerários terapêuticos e de intermedicalidade, recorrentes na antropologia do corpo e da saúde, não dão conta da descrição do sistema de cura casqueiro. Ao

\footnotetext{
${ }^{18}$ Gostaria atentar para a possibilidade da existência de "intermedicalidade" em níveis como o inter-religioso descrito por López (2016), no qual dentro de um hospital um espaço ecumênico é criado para atender demandas sociais da população negra em Porto Alegre.
} 
contrário disso, em prol da ideia da pura e simples busca da eficácia curativa, proponho o uso da noção de agenciamentos, para um sistema rizoma que captura, conecta e descarta tratamentos baseado na criatividade das benzedeiras, de um lado, e dos próprios pacientes, de outro. Isso sem, entretanto, que "pacientes" e benzedeiras sejam pares opostos do sistema.

$* * * * *$

Por fim, deixo uma provocação que me fora colocada em um congresso: mas afinal qual seria a política que poderia ser aplicada tendo como base a medicina diferenciada e tradicional do quilombo? Naquela vez não soube responder, precisava conversar com meus amigos da Casca. $\mathrm{O}$ caso é que, se o estudo da "intermedicalidade" para Arruti (2008) é capaz de propiciar uma "melhoria nas políticas de promoção da saúde específicas", o estudo dos agenciamentos do sistema de cura local no Quilombo da Casca apontam para um caminho distinto, no qual cabe às benzedeiras e pacientes gerir ontologias e ao Estado-Nação prover o mesmo direito e acesso ao SUS sem especificidade alguma, sua existência é que deve ser garantida - mesmo que para isso a rubrica formal venha acompanhada do adjetivo quilombola. Quanto à "saúde específica" cabe aos casqueiros a criatividade dos agenciamentos possíveis e únicos. $\mathrm{O}$ sistema de cura casqueiro é tão mais potente, quanto maior as possibilidades de agenciar, por isso a saúde pública basta estar disponível para entrar em relação.

Bibliografia

ANJOS, José Carlos Gomes dos. "Apresentação \& O território e o sistema de cura". In: \& SILVA, Sergio Baptista da (Orgs.). São Miguel e Rincão dos Martiminianos: ancestralidade negra e direitos territoriais. Porto Alegre: UFRGS, 2004.

ARRUTI, José Maurício. Políticas públicas para quilombos - Um ensaio de conjuntura a partir do exemplo da Saúde. In: http://www.koinonia.org.br/tpdigital/detalhes.asp?cod_artigo=208\&cod_bolet $\mathrm{im}=12 \&$ tipo=Artigo (2008), acessado em março de 2009.

CAMARGO JR., Kenneth Rochel de. “A Biomedicina”. In: Physis. Revista de Saúde Coletiva. Rio de Janeiro, 2005.

DELEUZE, Gilles. Diálogos. Lisboa: Relógio d’Água, 2004.

DELEUZE, Gilles. \& GUATTARI, Félix. Mil Platôs: capitalismo e esquizofrenia, vol. 1. São Paulo: Ed. 34, 1995.

EVANS-PRITCHARD, E.E. Bruxaria, oráculos e magia entre os azande. Rio de Janeiro: Zahar, 2005.

FOLLÉR, Maj-Lis, "Intermedicalidade: a zona de contato criada porpovos indígenas e profissionais de saúde. In: Esther J. Langdon e Luiza Garnelo (orgs.). Saúde dos Povos Indígenas: Reflexões sobre Antropologia 
Participativa. Rio de Janeiro, Associação Brasileira de Antropologia, 2004, pp. 129-147

GUATTARI, Félix. \& ROLNIK, Suely. Micropolítica Cartografias do Desejo. Petrópolis: Vozes, 1996.

INGOLD, Tim. "Trazendo as coisas de volta à vida: emaranhados criativos num mundo de materiais". In: Horizontes Antropológicos, ano 18, n⿳0 37, 2012, pp. 25-44.

LATOUR, Bruno. Jamais Fomos Modernos. São Paulo: Ed. 34, 1996.

LEITE, Ilka Boaventura. O legado do testamento: a comunidade de Casca em perícia. 2.ed. Porto Alegre: Ed. da UFRGS, 2004.

LÓPEZ, Laura C. "Corporificação e territorialização das religiões afro-brasileiras no Sistema Único de Saúde”. In: Política \& Trabalho. Revista de Ciências Sociais. No 44, jan/jun de 2016, pp. 109-124.

MENÉNDEZ, Eduardo L. "Modelos de atención de los padecimentos: de exclusiones teóricas y articulaciones práticas”. In: Ciência e Saúde Coletiva, 8 (1), 2003, pp. 185-207.

NATHAN, Tobie. "Manifeste pour une psychopathologie scientique". In: NATHAN, Tobie. \& STENGERS, Isabelle. Médicins et Sorciers, Paris: Le Seuil, 2004.

OLIVEIRA, Elda Rizzo de. "Eficácia simbólica de cura e razão analógica”. In: XI Ciclo de Estudos sobre o Imaginário. Recife: PPGA/UFPE, 2000.

\section{Recebido em 31/10/2016.} Aprovado em 11/11/2016. 